\title{
Dermatite de Contacto Alérgica em Profissionais de Saúde
}

\author{
Vítor Pinheiro', Catarina Pestana', Francisco Marques', André Pinho², Isabel Antunes', Margarida Gonçalo³ \\ 'Interno de Formação Específica em Medicina do Trabalho no CHUC, Serviço de Saúde Ocupacional. Centro Hospitalar e \\ Universitário de Coimbra, Coimbra, Portugal \\ ${ }^{2}$ Serviço de Dermatologia. Centro Hospitalar e Universitário de Coimbra, Coimbra, Portugal \\ ${ }^{3}$ Clínica de Dermatologia. Faculdade de Medicina. Universidade de Coimbra, Coimbra, Portugal
}

RESUMO - Introdução: A dermatite de contacto alérgica (DCA) constitui patologia profissional particularmente frequente em profissionais de saúde. Os alergénios responsáveis podem variar ao longe do tempo, com a exposição ocupacional e com o tipo de trabalho. Objectivos e Métodos: Com o objetivo de avaliar a realidade local, foi feita uma análise retrospetiva dos profissionais de saúde que realizaram testes epicutâneos no Serviço de Dermatologia do Centro Hospitalar e Universitário de Coimbra (CHUC), num período de 6 anos (2010-2015), por suspeita de dermatite de contacto alérgica. Os doentes foram todos testados com uma Série Básica e com séries complementares orientadas pela história clínica. Resultados: Dos 1858 doentes testados, 125 (6,7\%) eram profissionais de saúde, 114 de género feminino/11 masculino, idade média de 39,26 12,5 anos, maioritariamente enfermeiras (56), assistentes técnicos (48) e médicos (21), 71 com dermatite das mãos (56.8\%), 22 com dermatite atópica e/ou outros sinais de atopia $(17,6 \%)$. Noventa (72\%) revelaram pelo menos um patch test (PT) positivo, 47 dos quais (52,2\%) com relevância profissional. Doentes com dermatite das mãos tiveram mais frequentemente PT positivo $(76,1 \%)$. Os metais causaram maior número de PT positivos (total 51; Ni-41, maioritariamente com relevância passada, Co-8; Cr-2), seguidos das fragrâncias (total 30; mistura de fragrâncias (FM)-I-10; Myroxylon pereirae-8; lyral-5; FM-II-4; citronellol-3), conservantes (total 29, dos quais 20 à metilisotiazolinona (MI) e/ou clorometilisotiazolinona/MI (MCl/MI)), borrachas (24; P-fenilenodiamina (PPD)/Isopropil-PPD-9) e medicamentos tópicos (total 14; iodopovidona 5). As principais causas da DCA profissional foram os desinfetantes/sabonetes líquidos e produtos de higiene dos doentes (15), borracha das luvas/calçado (12) e medicamentos sistémicos ou tópicos (8 antissépticos e 3 antibióticos parentéricos). Os principais alergénios com relevância profissional foram a Ml e/ou MCl/MI (15), lanolina (9), formaldeído e/ou libertadores (7), iodopovidona (5), carbamatos (4), FM-I (3), cefalosporinas (3) e acrilatos (3 dentistas e/ou assistentes dentários). Em 37 dos 42 casos avaliados, houve uma melhoria franca ou resolução da DCA, após evicção do alergénio causal, nomeadamente o conservante $\mathrm{MCl} /$ MI contido num sabonete líquido sob a designação de "Acticide ${ }^{\circledR} M V^{\prime}$. Conclusões: A dermatite das mãos, a principal apresentação da DCA em profissionais de saúde, não mostrou relação com atopia e foi mais frequentemente associada a PT positivos. PT positivos a isotiazolinonas e libertadores de formaldeído foram mais frequentes entre profissionais de saúde do que na população geral estudada, muito provavelmente devido à exposição cumulativa, pessoal e profissional, a estes conservantes em sabonetes líquidos de uso pessoal e hospitalar. O PT foi crucial para orientar individualmente os doentes e para alertar a comunidade hospitalar para a presença de alergénios no local de trabalho e estabelecer medidas preventivas mais adequadas.

PALAVRAS-CHAVE - Alergénios; Dermatite de Contacto Alérgica; Exposição Ocupacional; Profissionais de Saúde; Saúde Ocupacional; Testes de Contacto

\section{Occupational Allergic Contact Dermatitis in Healthcare Workers}

ABSTRACT - Introduction: Occupational allergic contact dermatitis (ACD) is frequent among health care workers (HCW) and culprit allergens may vary with time, occupational setting and exposure hazards. Objectives and Methods: In order to

Apresentações e Prémios: Apresentado no Congresso: "Occupational contact dermatitis in healthcare workers", European Society of Contact Dermatitis, 14-17 Sep, 2016, Manchester, UK.

Presentations and Awards: Presented at the Congress: "Occupational contact dermatitis in healthcare workers", European Society of Contact Dermatitis, 14-17 Sep, 2016, Manchester, UK.

Correspondência: Vítor César Arantes Pinheiro

Serviço de Saúde Ocupacional - Centro Hospitalar e Universitário de Coimbra

Rua José Pinto Loureiro ${ }^{\circ} 49$ rch/esq - 3000-235 Coimbra, Portugal

Tel.: + 351913416119

E-mail: vitorpinheiro125@gmail.com
Recebido/Received

20 Dezembro/December 2016

Aceite/Accepted

20 Fevereiro/February 2017 
characterize the main contact allergens in HCW with dermatitis and its occupational relevance, we performed a retrospective analysis of clinical data and patch test (PT) results from HCW who were studied in the Department of Dermatology of Coimbra Hospital and University Centre (CHUC) between 2010-2015. All patients were tested with a baseline and additional series, according to the tasks developed. Results: Among 1858 patch tested patients, 125 (6.7\%) were HCW, 114 females/11 males, mean age 39,26 12,5 years, mainly nurses (56), technical assistants (48) and doctors (21), 71 with hand dermatitis (56,8\%), 22 with atopic dermatitis and/or other atopic symptoms (17,6\%). Ninety patients (72\%) had at least one positive PT, 47 $(37,6 \%)$ with occupational relevance. Patients with hand dermatitis were significantly more likely to have positive PT (76.1\%). We observed 51 positive PT to metals (Ni-41, most with past relevance, Co-8; Cr-2), 30 to fragrances (FM-I-10; Myroxylon pereirae-8; lyral-5; FM-II-4; citronellol-3), 29 to preservatives (mostly methylisothiazolinone (MI) and/or chloromethylisothiazolinone (MCI)-20), 24 to rubber chemicals (P-phenylenediamine (PPD)/Isopropyl-PPD-9), and 14 to topical medicaments (iodopovidone - 5; caine mix - 4). The main occupational causes of ACD were hand soaps/disinfectants and patients' hygiene products (15), protective gloves/shoes-9 and topical or systemic drugs (antiseptics-8 and parenteral antibiotics-3). Main allergens with occupational relevance were $\mathrm{MI}$ and/or $\mathrm{MCl} / \mathrm{MI}$ (15), although isolated $\mathrm{MI}$ was tested only after mid 2012, lanolin and/or amerchol L101 (9), formaldehyde and/or formaldehyde releasers (7), iodopovidone (5), thiuram mix (5), carbamates (4), FM-I (3), cephalosporins (3) and (meth)acrylates (3 dentists/dental technicians). In 37 out of 42 evaluated cases there was marked improvement/resolution of the dermatitis, namely after eviction of the hospital hand soap which contains $\mathrm{MCl} /$ $\mathrm{Ml}$ under the designation of Acticide ${ }^{\circledR}$ MV. Conclusions: Hand dermatitis was the main presentation of ACD in HCW with no apparent relation with atopy. Isothiazolinones and formaldehyde releasers induced more positive PT and were more frequent among HCW than in the whole population studied very probably due to the cumulative exposure to these preservatives in personal and occupational hand soaps and hygiene products. PT was important to orient eviction in each individual case but also for the hospital community to understand the presence of moderate or potent sensitizers in the work place and, therefore, establish the most adequate preventive measures.

KEYWORDS - Allergens; Dermatitis, Allergic Contact; Health Personnel; Occupational Exposure; Occupational Health; Patch Tests.

\section{INTRODUCTION}

Occupational skin diseases are very frequent representing up to $34 \%$ of the occupational diseases recorded in Europe. ${ }^{1}$ The Portuguese reality is not well documented as occupational skin diseases are seldom reported to the national authorities. ${ }^{2}$ Contact dermatitis represents one of the most common occupational disease ${ }^{3-6}$ and it is frequently responsible for sick-leave ${ }^{7}$, job loss and disability resulting in chronicity and high socio-economic impact..$^{710}$ Moreover it can have a high impact on quality of life. ${ }^{9,10}$ Occupational allergic contact dermatitis (ACD) is particularly frequent among health care workers (HCW). ${ }^{1,5,6,11-14}$

In the healthcare setting ACD can occur due both to delayed-type hypersensitivity mediated by allergen specific $T$ lymphocytes that recognize low molecular weight chemicals, and immediate-type hypersensitivity, with IgE recognizing larger chemicals, like latex proteins. ${ }^{12,15,16}$ Clinical manifestations depend on the chemical properties of the allergens, local and form of exposure (acute or chronic) ${ }^{17,18}$ and may also be influenced by individual factors (atopy) or concomitant risk factors, like intensive exposure to wet work and skin irritants, namely with frequent and cumulative hand washing at work and at home. ${ }^{19}$ Occupational ACD in HCW affects mainly the hands, and particularly females, younger workers, individuals working in acute care settings, facility support services, and laboratory assistants and technicians, due to the tasks required..$^{20} \mathrm{ACD}$ is reported to be mainly due to contact with rubber chemicals of protective gloves, surface and instrument disinfectants, drugs for systemic or topical use, or components of skin care products such as emollients, barrier creams, or liquid soaps ${ }^{12-14,19}$ but culprit allergens may vary with time, occupational setting and exposure hazards. A correct diagnosis of occupational ACD is critical once the timeline of the diagnosis affects the outcome of the disease. ${ }^{21}$ The diagnostic work-up of ACD includes a complete physical examination, a detailed occupational history (exposure at work, use of personal protective equipment, work and skin care practices, relationship of the symptoms with work and whether other workers are also affected), and a fundamental step, patch testing, the most important investigative and diagnostic method available for studying the aetiology of delayed contact hypersensitivity. ${ }^{1622}$

There is lack of data in Portuguese healthcare centres, ${ }^{2 ; 28}$ but we have reasons to believe, according to findings in literature, 1,6,19,23-29 that targeted interventions based on well documented risk factors and allergens may provide a particularly beneficial cost-benefit effect in HCW, particularly in hand eczema. ${ }^{7,9}$ In order to manage properly the occupational $A C D$, detailed information on the incidence and causes of occupational ACD is needed.

\section{AIMS}

The aim of the present study was to evaluate the prevalence of delayed-type hypersensitivity reactions in $\mathrm{HCW}$ with dermatitis, focusing on characterization of the main contact allergens and its occupational relevance, in comparison with the whole population tested.

A secondary aim was evaluate the subsequent results of the measures taken after the correct etiologic diagnosis on the outcome of the dermatitis. 
Table 1 - Comparative characteristics of healthcare workers and the whole patch tested population between 2010 and 2015.

\begin{tabular}{|c|c|c|c|}
\hline \multicolumn{2}{|c|}{ TOTAL PATIENTS TESTED } & HCW & DIFFERENCES \\
\hline Total studied & 1858 & 125 & \\
\hline PT positive & 1295 (69.85\%) & 90 (72.00\%) & $\leftrightarrow$ \\
\hline PT positive in males & 308 (61.52\%) & 5 (45.45\%) & $\downarrow$ \\
\hline \multicolumn{4}{|c|}{ MOHALFA Index } \\
\hline Male & 479 (25.82\%) & $11(8.80 \%)$ & $\downarrow$ \\
\hline Atopy/atopic dermatitis & $543(29.24 \%)$ & 22 (17.6\%) & $\downarrow$ \\
\hline Leg ulcer/dermatitis & $121(6.54 \%)$ & $0(0.00 \%)$ & $\downarrow$ \\
\hline Face dermatitis & 506 (27.28\%) & 29 (23.2\%) & $\leftrightarrow$ \\
\hline Age $>40$ & 953 (51.34\%) & $54(43.2 \%)$ & $\downarrow$ \\
\hline
\end{tabular}

\section{METHODS}

We performed a retrospective analysis of clinical data and patch test (PT) results from HCW studied in the allergology section of the Department of Dermatology of Coimbra University Hospital (CHUC) between 2010-2015. All patients were tested with the European baseline ${ }^{30}$ and additional series, according to the tasks they developed. Allergens from Chemotechnique (Chemotechnique Diagnostics ${ }^{\circledR}$, Vellinge, Sweden) or Trolab allergens ${ }^{\circledR}$ (Almirall GmbH, Germany) were applied for $48 \mathrm{~h}$ on the back using Finn Chambers ${ }^{\circledR}$ (Epitest Ld, Almirall) or IQ Chambers ${ }^{\circledR}$ (Chemotechnique Diagnostics ${ }^{\circledR}$, Vellinge, Sweden) and readings were performed at day (D)2-3 and D4-7, according to ESCD guidelines. ${ }^{30-32}$ Only $1+$ or more intense reactions were considered. Occasionally, semi-open testing was performed with rinse-off products from the workplace. MOHAL-FA index of the HCW population was evaluated and compared with the whole population tested.

\section{PATIENTS}

Between 2010 and 2015, among a total of 1858 patients that were patch tested in the Department, we studied 125 (6.7\%) HCW, 114 females (91.2\%) and 11 (8.8\%) males, with a maximum age of 68 and a minimum of 21 years (average 39.26 years \pm 12.54$), 56$ nurses, 48 technical assistants and 21 physicians (Table 1). Comparing with the whole population, there was a female predominance in $\mathrm{HCW}$ and hands were more frequently affected (56.8\%) in this group of patients.

\section{RESULTS}

Among the $125 \mathrm{HCW}$ that were patch tested, the main clinical presentation that motivated the allergological study was hand eczema (71-56.8\%), followed by facial lesions (29-23.2\%).

Out of the $125 \mathrm{HCW}$, ninety patients (72\%) had at least one positive PT. Considering the European baseline series, the most frequent allergens identified were metals (51 - mostly nickel sulphate), fragrances (30, fragrance mix I - 10 and Myroxylon pereirae - 8), preservatives (29, namely isotiazolinones - 20 and formaldehyde and/ or formaldehyde releasers - 9), and rubber chemicals (28, namely paraphenylenediamine(PPD)/IsopropyIPPD in 13 cases; thiuram mix and carba mix 5 cases each) and topical medicaments (14, namely iodopovidone 5 cases and caine mix - 4) (Table 2). Nickel sulphate was the most frequent allergen (41-45.6\%), with most cases related to past relevance, followed by methylisothiazolinone (MI) and/or chloromethylisothiazolinone/methylisothiazolinone $(\mathrm{MCl} /$ MI) that together had 20 cases (22.2\%), and thimerosal (19$21.1 \%)$.

In the 90 reactive patients we found 179 total positive PT within the baseline series, 57 (31.8\%) with occupational relevance, and 150 more positive PT in additional series, 72 (48.0\%) with occupational relevance.

A positive PT with occupational relevance was observed in 47 of the 90 reactive patients (52.2\%), in 54 out of 


\section{GPDEC}

Table 2 - Most common positive PT within the baseline series in HCW and its occupational relevance.

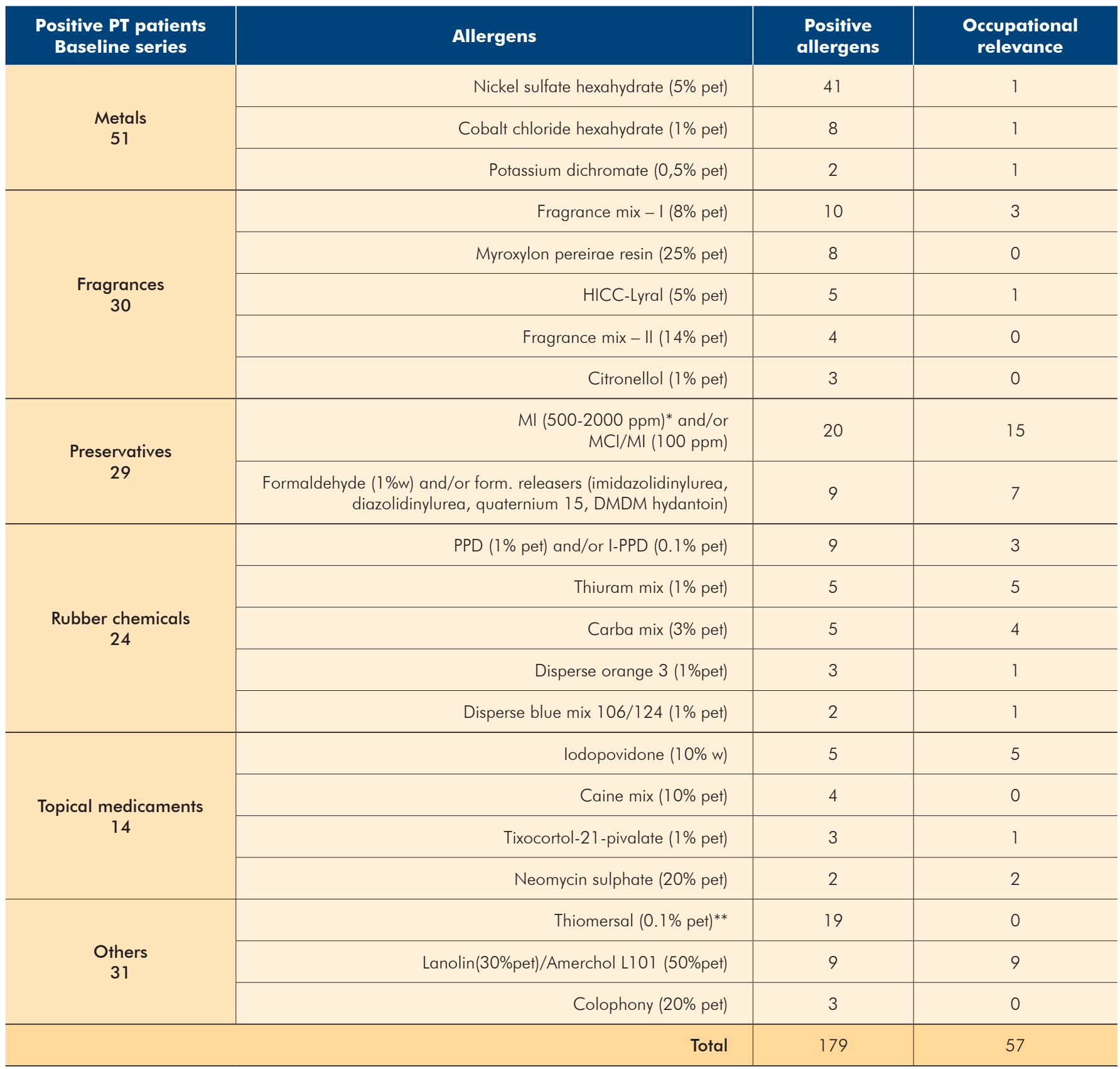

DMDM hydantoin - Dimethylol dimethyldydantoin; I-PPD - Isopropyl-paraphenylendiamine; HICC - Hydroxyisohexyl 3-cyclohexene carboxaldehyde; MCI - mehtylchloroisothiazolinone; $\mathrm{MI}$ - mehtylisothiazolinone; PPD - paraphenylendiamine.

*tested only after mid 2012 and untill 2014 only at 500 ppm

** thiomersal tested in the baseline séries only until 2014

$71(76.1 \%)$ patients with hand dermatitis and 16 out of 25 (64\%) with atopy and atopic dermatitis.

The main occupational causes of ACD were hand soaps/ disinfectants and patients' hygiene products (15), protective gloves/shoes (9) and topical or systemic drugs (antiseptics-7 and parenteral antibiotics-3). The main allergens with occupational relevance are described on Table 2 and Table 3.
Although isolated MI was tested only after mid 2012 and initially at $500 \mathrm{ppm}$ in water it was the most common allergen, very often with occupational relevance related with the use of a hand soap containing $\mathrm{MCl} / \mathrm{Ml}$, under the designation of Acticide $M V^{\circledR}$. Occupational $A C D$ to cephalosporins was observed in 3 nurses that manipulated the antibiotics during its preparation, and 3 cases of ACD to (meth)acrylates were 
Table 3 - Most common positive PT allergens in HCW and its occupational relevance within additional series.

\section{Additional Series}

Cosmetics

29

Acrylates and

Methacrylates - 26

Hand soaps - 25

Rubber chemicals and other glove allergens - 16

\begin{tabular}{|c|c|c|}
\hline Allergens & $\begin{array}{l}\text { Positive } \\
\text { allergens }\end{array}$ & $\begin{array}{l}\text { Occupational } \\
\text { relevance }\end{array}$ \\
\hline Propolis (10\% pet) & 5 & 1 \\
\hline Cocamidopropyl betaine (1\% w) & 3 & 1 \\
\hline Benzophenone-3 (10\% pet) & 3 & 1 \\
\hline DMDM Hydantoin ( $2 \%$ w) & 2 & 0 \\
\hline Ethyilenediamine dihydrochloride (1\% pet) & 2 & 1 \\
\hline Chlorhexidine digluconate ( $0.5 \%$ pet) & 1 & 1 \\
\hline Dimethylamino-propylamine (1\% w) & 2 & 1 \\
\hline 2-bromo,2-nitropropanodiol (bronopol) (0.5\% pet) & 1 & 1 \\
\hline Sodium metabisulfite (1\% pet) & 1 & 1 \\
\hline Hydroabietyl alcohol (10\% pet) & 1 & 0 \\
\hline Tolvenesulfonamide formaldehyde resin ( $10 \%$ pet) & 1 & 0 \\
\hline Sorbitan oleate (5\% w) & 1 & 0 \\
\hline Chloroacetamide (0.2\% pet) & 1 & 0 \\
\hline Hexahydro-1.3.5-tris-(2-hydroxyethyl)triazine-Grotan Bk (1\% w) & 1 & 0 \\
\hline Oleamidopropyl dimethylamine $(0.1 \% \mathrm{w})$ & 1 & 0 \\
\hline Trietalonamine ( $2.5 \%$ pet) & 1 & 0 \\
\hline Benzoic acid (5\% pet) & 1 & 0 \\
\hline Triclosan (2\% pet) & 1 & 0 \\
\hline 2-OH-ehtyl metacrylate HEMA (1\% pet) & 7 & 2 \\
\hline 2-OH-propylmetacrylate HPMA (2\% pet) & 7 & 2 \\
\hline Ethylene gycol dimethacrylate EGDMA (2\% pet) & 3 & 1 \\
\hline Triethylene glycol dimethacrylate (2\% pet) & 3 & 1 \\
\hline Tetra Ethylene gycol dimethacrylate (2\% pet) & 2 & 0 \\
\hline Ethyl acrylate (0.1 pet) & 2 & 0 \\
\hline Dimethylaminoethyl metacrylate ( $0.2 \%$ pet) & 2 & 0 \\
\hline Hand cleansers (as is in semi-open testing) & 9 & 6 \\
\hline Dishwashing detergents (as is in semi-open testing) & 9 & 5 \\
\hline Softaskin $^{\circledR}$ & 4 & 4 \\
\hline Lifoscrub $^{\circledR}$ & 2 & 2 \\
\hline Promanun $^{\circledR}$ & 1 & 1 \\
\hline 1.3-Diphenylguanidine (1\% pet) & 3 & 3 \\
\hline Bensoisothiazolinone (0.1\% pet) & 2 & 2 \\
\hline Tetramethylthiuram monosulf. (0.25\% pet) & 2 & 2 \\
\hline Tetramethylthiuram dissulf. (0.25\% pet) & 2 & 2 \\
\hline N.N-Diphenyl-p-phenylenediamine (0.25\% pet) & 2 & 2 \\
\hline Dipentamethylenethiuram dissulf. (0.25\% pet) & 1 & 1 \\
\hline Disperse Red 1 (1\% pet) & 1 & 1 \\
\hline Acid yellow 36 (1\% pet) & 1 & 1 \\
\hline 4.4-Diaminophenylmethane (0.5\% pet) & 1 & 0 \\
\hline Latex (1\% pet) & 1 & 1 \\
\hline
\end{tabular}




\section{GPDEC}

Table 3 (Cont.) - Most common positive PT allergens in HCW and its occupational relevance within additional series.

\begin{tabular}{|c|c|c|c|}
\hline Additional Series & Allergens & $\begin{array}{l}\text { Positive } \\
\text { allergens }\end{array}$ & $\begin{array}{l}\text { Occupational } \\
\text { relevance }\end{array}$ \\
\hline \multirow{9}{*}{ Fragrances - 12} & Tree moss absolute ( $1 \%$ pet) & 2 & 1 \\
\hline & Balsam of Tolu (20\% pet) & 2 & 1 \\
\hline & Geraniol (1\% pet) & 2 & 2 \\
\hline & Oak moss absolute ( $1 \%$ pet) & 1 & 1 \\
\hline & Alfa-amylcinamal (1\% pet) & 1 & 1 \\
\hline & Propionic acid (3\% pet) & 1 & 0 \\
\hline & Sorbitan sesquioleate ( $20 \%$ pet) & 1 & 0 \\
\hline & Trans-anethole (5\% pet) & 1 & 0 \\
\hline & Hydroxycitronellal (1\% pet) & 1 & 0 \\
\hline \multirow{2}{*}{ Metals - 11} & Palladium chloride ( $2 \%$ pet) & 10 & 0 \\
\hline & Vanadium (5\% pet) & 1 & 1 \\
\hline \multirow{6}{*}{ Topical drugs - 10} & Polyninylpirrolidone iodade (2\% w) & 4 & 4 \\
\hline & Nonoxynol 9 (2\% pet) & 1 & 1 \\
\hline & Polyninylpirrolidone iodade (10\% pet) & 2 & 2 \\
\hline & Cloridrate benzalconio $(0.1 \%$ pet $)$ & 1 & 1 \\
\hline & Sulphate Gentamicyn (20\% pet) & 1 & 1 \\
\hline & Hydrogen peroxide $(3 \% \mathrm{w})$ & 1 & 1 \\
\hline \multirow{7}{*}{ Systemic antibiotics - 9} & Cefotaxim sodium salt ( $10 \%$ pet) & 2 & 2 \\
\hline & Ceftriaxone (10\% pet) & 2 & 2 \\
\hline & Cefazolin (10\% pet) & 1 & 1 \\
\hline & Ampiciline (10\% pet) & 1 & 1 \\
\hline & Cefoxitin (10\% pet) & 1 & 1 \\
\hline & Omeprazole (10\% pet) & 1 & 0 \\
\hline & Pantoprazole (10\% pet) & 1 & 0 \\
\hline \multirow{5}{*}{ Hairdressers - 6} & Tuolene-2.5-diamine sulphate (1\% pet) & 2 & 0 \\
\hline & Pirogalol (1\% pet) & 1 & 0 \\
\hline & Wood tar mix (12\% pet) & 1 & 0 \\
\hline & Aminophenol (1\% pet) & 1 & 0 \\
\hline & 2-nitro-p-phenylenediamine ( $1 \%$ pet) & 1 & 0 \\
\hline \multirow{2}{*}{ Anaesthetics - 3} & Tetracaine hydrochloride (5\% pet) & 2 & 1 \\
\hline & Lidocaine (5\% pet) & 1 & 0 \\
\hline \multirow[t]{2}{*}{ Personal systemic drugs - 3} & Cloropromazina $^{\oplus} ;$ Fenofibrato $^{\oplus}$; Pravafenix ${ }^{\circledast}$ & 3 & 0 \\
\hline & Total & 150 & 72 \\
\hline
\end{tabular}

found among dentists/dental technicians (Fig. 1 and 2).

Thimerosal, patch tested only until 2014, had a high prevalence in our patients, but its occupational relevance is difficult to consider as its use as a skin disinfectant was discontinued long ago in healthcare centres in our country.

After the identification of the causal allergens, personal measures to reduce/avoid exposure were taught to the patients who were later observed in consultation or contacted by phone in order to know the outcome of their dermatitis. Marked improvement or resolution of the dermatitis was observed in 37 out of $42(88 \%)$ cases that were evaluated, namely after eviction of the hospital hand soap which contains $\mathrm{MCl}$ / MI. Nevertheless, although efforts were conducted to replace this soap, these measures were not yet fully accomplished. 

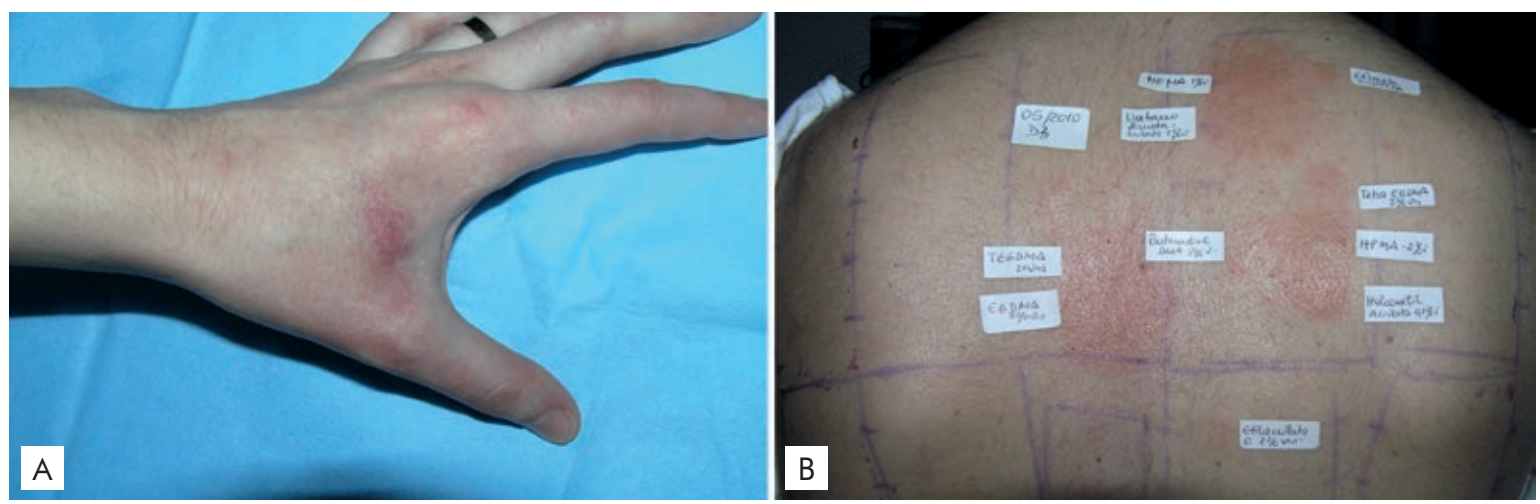

Figure 1 - Hand dermatitis involving the dorsum of the hand in a dentist who inadvertently applied the acrylate sealant on the glove before performing the treatment $(\mathrm{A})$ and the relevant reaction to multiple acrylates and methacrylates (B).
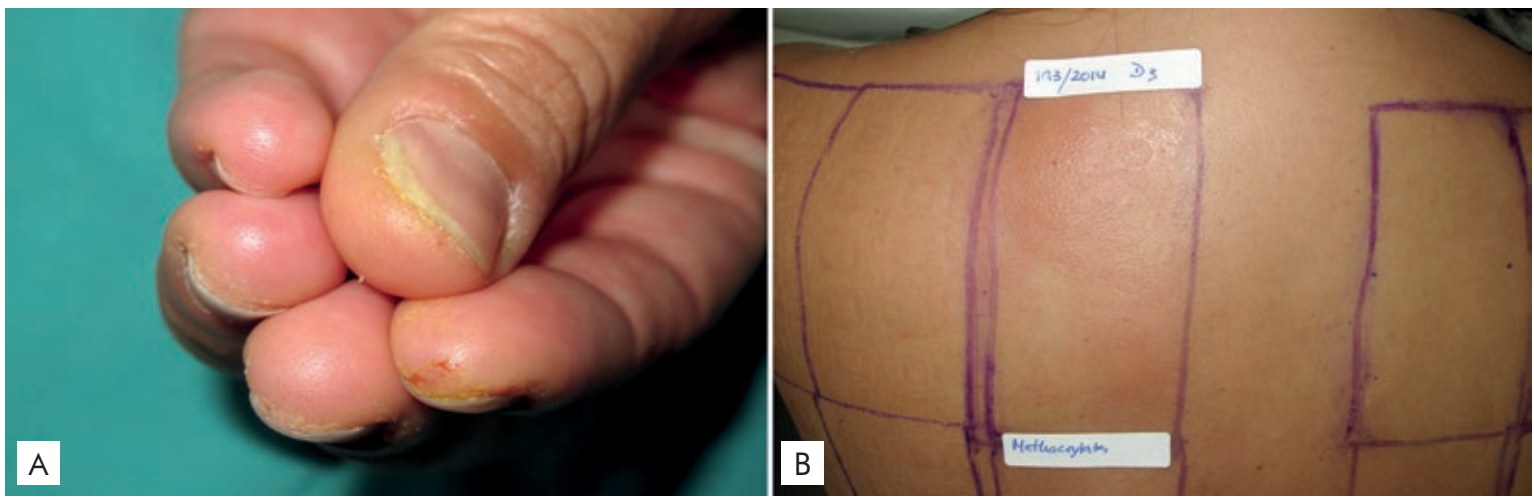

Figure 2 - Pulpitis with fissures in a dentist (A), the most frequent pattern of ACD among dental workers and reactivity to several (meth)acrylates (B).

\section{DISCUSSION}

As previously reported, positive PT and ACD were frequently observed in HCW. ${ }^{1,11-13}$ Actually, more than $70 \%$ of the studied HCW had a positive PT, which is not significantly different from the whole population tested. Although, only about half of the reactive patients had an occupationally relevant positive PT, occupational ACD was documented in $38 \%$ of the HCW that searched a dermato-allergology testing, much higher than the percentage of occupational cases in the whole population tested (16\%).

The majority of the study group were women (91.2\%), which is due to the large proportion of nurses where women constitute the majority of the staff. This may also explain the high frequency of PT reactions to nickel and the slightly higher PT reactivity in the whole group.

Hand dermatitis was the main presentation of $A C D$ in $\mathrm{HCW}$, consistent with other studies. ${ }^{12,19}$ Although hand dermatitis is a multifactorial disease, often combining also atopic dermatitis, chronic irritant contact dermatitis, immediate symptoms, like contact urticaria and protein contact dermatitis, ${ }^{33}$ the high frequency of ACD in this subgroup is certainly explained by the tasks done mainly by hand, like frequent washing and use of hand soaps/disinfectants and protective gloves. ${ }^{19}$ Moreover, wet work and the irritant effect of some of these substances, also favours sensitization in hand dermatitis. ${ }^{34}$ Interestingly, in our study there was no apparent relation between positive PT and atopy.

There are few published data on the prevalence of sensitized HCW and respective culprit allergens in Portuguese hospitals. ${ }^{2,35}$ Patch testing based in European baseline series, is widely used in European dermatology units for patch testing, and includes contact allergens found in occupational and non-occupational or both settings. Here we found 179 positive PT in European baseline series, 57 (31.8\%) of them with occupational relevance, but we also found 150 positive PT, still with a higher percentage $(48.0 \%)$ of occupationally relevant reactions when aimed testing with additional series. This finding highlights the importance of patch testing with additional series when ACD is suspected in HCW, namely when considering dental technicians and specific exposures as topical and systemic drugs which are not included in the baseline series.

Nickel was the most common allergen, as previously reported ${ }^{36}$, with sensitization rates in women similar to the whole Portuguese population, probably explained by the poor implementation of the nickel Directive in Portugal ${ }^{37}$, but it was not considered of occupational relevance, as this metal allergy is seldom related to this occupational setting. ${ }^{38,39}$

Apart from nickel, overall, occupational relevance of PT 
in $\mathrm{HCW}$ was high $(52.2 \%)$ and eviction measures were important to improve or clear the dermatitis, as shown with the good outcome of our patients where relevant allergens were found. Like in other studies, main occupational relevant allergens were the preservatives, ${ }^{1,6,12,13,40}$ rubber chemicals, ${ }^{12,13}$ topical drugs and lanolin. ${ }^{1,12}$ High reactivity to preservatives, with 20 cases from isothiazolinones and 7 from formaldehyde and/or formaldehyde releasers, is very probably due to the cumulative personal and occupational exposure, as preservatives as well as fragrance allergens are common to hospital hand soaps, patient hygiene products and personal hygiene products. Accordingly, isothiazolinones have gained notoriety in the last years as an emerging contact allergen ${ }^{41-44}$, present in wet wipes, skin cleansers, liquid soaps, lotions, shampoos and conditioners. ${ }^{1,42,43,45-49}$ Together with rubber chemical accelerators, $\mathrm{Ml}$ and or $\mathrm{MCl} / \mathrm{Ml}$ are associated with at least doubled risk of occupational ACD. ${ }^{1}$ Moreover, we found 2 positive PT to benzisothiazolinone very probably related to gloves, as this preservative is increasingly used in PVC and other gloves for medical use. ${ }^{50}$

Rubber chemicals in gloves and/or shoes are still one of the most common allergens in $\mathrm{HCW}, 1,6,11,12,19,51,52$ however the paradigm is changing in the last decade by the introduction of new allergens ${ }^{53}$ and new types of gloves. Vinyl gloves do not usually contain these rubber addictive, so this is the usual alternative for HCW with ACD caused by vulcanization accelerators in rubber gloves material.

PT reactivity to topical medicaments with occupational relevance was also high, according to the previous findings in literature, ${ }^{11}$ and it is justified by its frequent use in workplace particularly the antiseptics polivinylpirrolidone and chlorhexidine. Thimerosal, once used frequently as an antiseptic in most healthcare centres is still frequently responsible for positive PT, but relevance could not be traced, which justified its removal from the baseline series in 2014. Reactivity to thimerosal reflects either a high level of prior sensitization to this allergen or sensitization by vaccinations against infectious diseases such as influenza and hepatitis. ${ }^{13,36}$ Lanolin, present both in topical drugs and protective hand creams was also a frequent allergen in $\mathrm{HCW}$, as previously reported. ${ }^{1,12}$

Apart from topical drugs, we also identified a rare cause of occupational ACD to systemic drugs, ${ }^{54-56}$ in 3 cases of nurses sensitized to cephalosporins. Contact sensitivity to systemically administered drugs in HCW is mostly caused by antibiotics such as penicillins, cephalosporins and aminoglycosides ${ }^{54,55}$ and can be due to inadvertent contact with drug solutions for parenteral administration or, occasionally, by allergens in aerosols preparations or from the powder of pills crushed to administer to patients with swallowing problems. ${ }^{54,55}$

In dental HCW we found, as expected, sensitization to (meth)acrylates used in dental procedures, as prosthodontic restorations, ${ }^{57}$ but most cases of (meth)acrylate allergy were related with the use of artificial nails or long lasting acrylate nail varnish, ${ }^{2,58}$ a procedure still allowed in our HCW.

Our study emphasizes the importance of patch testing in
$\mathrm{HCW}$, to identify the allergens and orient eviction in each individual case, which, as previously reported was associated with a relatively good outcome. ${ }^{21}$ Moreover, it was also important for the hospital community to understand the presence of moderate or potent sensitizers in the work place and, therefore, establish the most adequate preventive measures. ${ }^{21,22,59}$ It is particularly noteworthy that patch testing allowed us to discover the $\mathrm{MCl} / \mathrm{Ml}$ under the designation of Acticide $\mathrm{MV}^{\circledR}$, in the hospital hand soap.

The occupational health team has a critical role in managing the exposure to hazardous allergens in workplace and identifying potential incidents. This work reinforces that $\mathrm{HCW}$ with dermatitis should follow skin care programmes, as the use alcohol-based hand gel for hand decontamination, which is less probable to induce ACD than commercial hand cleansers. ${ }^{12,21}$ Also, when hands are not visibly dirty, they should be disinfected instead of repeated washing. ${ }^{19}$ And finally, skin conditioning creams without sensitizers, like fragrances or lanolin, should be available at hand washing areas.

Also, occupational physicians should check for $\mathrm{HCW}$ with symptoms in order to perform the correct diagnosis, treat the allergy, keep the worker away from the source of exposure, if possible eliminate the source or keep an eye on other exposed workers and therefore reduce occupational ACD. This may be important also because recently there is some evidence that dermatitis is more likely to be colonised with microorganisms than normal skin, although the higher risk of contamination to patients remains uncertain. ${ }^{21}$ Even though it is still questionable, caution is advised and prevention policies should be implemented in order to reduce hazards present in workplace and promote safer work practices.

Conflitos de interesse: Os autores declaram não possuir conflitos de interesse.

Suporte financeiro: $O$ presente trabalho não foi suportado por nenhum subsídio ou bolsa.

Confidencialidade dos dados: Os autores declaram ter seguido os protocolos do seu centro de trabalho acerca da publicação dos dados de doentes.

Protecção de pessoas e animais: Os autores declaram que os procedimentos seguidos estavam de acordo com os regulamentos estabelecidos pelos responsáveis da Comissão de lnvestigação Clínica e Ética e de acordo com a Declaração de Helsínquia da Associação Médica Mundial

Conflicts of interest: The authors have no conflicts of interest to declare.

Financing Support: This work has not received any contribution, grant or scholarship.

Confidentiality of data: The authors declare that they have followed the protocols of their work center on the publication of data from patients.

Protection of human and animal subjects: The authors declare that the procedures followed were in accordance with the regulations of the relevant clinical research ethics committee and with those of the Code of Ethics of the World Medical Association (Declaration of Helsinki). 


\section{REFERENCES}

1. Pesonen $M$, Jolanki $R$, Larese Filon F, Wilkinson $M$, Krecisz B, Kiec-Swierczynska $M$, et al. Patch test results of the European baseline series among patients with occupational contact dermatitis across Europe - analyses of the European Surveillance System on Contact Allergy network, 2002-2010. Contact Dermatitis. 2015;72:154-63.

2. Pestana C, Gomes R, Pinheiro V, Gouveia M, Antunes I, Goncalo M. Main Causes of Occupational Allergic Contact Dermatitis: A Three Year Study in the Center of Portugal. Acta Med Port. 2016;29:449-55.

3. Diepgen TL. Occupational skin diseases. J Dtsch Dermatol Ges. 2012;10:297-313; quiz 314-5.

4. Diepgen TL, Coenraads PJ. The epidemiology of occupational contact dermatitis. Int Arch Occup Environ Health. 1999;72:496-506.

5. Schnuch A, Uter W, Geier J, Frosch PJ, Rustemeyer T. Contact allergies in healthcare workers. Results from the IVDK. Acta Derm Venereol. 1998;78:358-63.

6. Molin S, Baver A, Schnuch A, Geier J. Occupational contact allergy in nurses: results from the Information Network of Departments of Dermatology 2003-2012. Contact Dermatitis. 2015;72:164-71.

7. van der Meer EW, Boot CR, van der Gulden JW, Jungbauer FH, Coenraads PJ, Anema JR. Hand eczema among healthcare professionals in the Netherlands: prevalence, absenteeism, and presenteeism. Contact Dermatitis. 2013;69:164-71.

8. Lau MY, Burgess JA, Nixon R, Dharmage SC, Matheson $M C$. A review of the impact of occupational contact dermatitis on quality of life. J Allergy. $2011 ; 2011$ :964509.

9. Matterne U, Apfelbacher CJ, Soder S, Diepgen TL, Weisshaar E. Health-related quality of life in health care workers with work-related skin diseases. Contact Dermatitis. 2009;61:145-51.

10. Brutti CS, Bonamigo RR, Cappelletti T, Martins-Costa GM, Menegat AP. Occupational and non-occupational allergic contact dermatitis and quality of life: a prospective study. An Bras Dermatol. 2013;88:670-1.

11. Warshaw EM, Schram SE, Maibach HI, Belsito DV, Marks JG, Jr., Fowler JF, et al. Occupation-related contact dermatitis in North American health care workers referred for patch testing: cross-sectional data, 1998 to 2004. Dermatitis. 2008; 19:261-74.

12. Higgins CL, Palmer AM, Cahill JL, Nixon RL. Occupational skin disease among Australian healthcare workers: a retrospective analysis from an occupational dermatology clinic, 1993-2014. Contact Dermatitis. 2016;75:213-22.

13. Malik M, English J. Irritant hand dermatitis in health care workers. Occup Med. 2015;65:474-6.

14. Kadivar S, Belsito DV. Occupational dermatitis in health care workers evaluated for suspected allergic contact dermatitis. Dermatitis. 2015;26:177-83.

15. Martin SF. Immunological mechanisms in allergic contact dermatitis. Curr Opin Allergy Clin Immunol 2015;15(2):124-30.
16. Ale IS, Maibacht HA. Diagnostic approach in allergic and irritant contact dermatitis. Expert Rev Clin Immunol. 2010;6:291-310.

17. Peng W, Novak N. Pathogenesis of atopic dermatitis. Clin Exp Allergy. 2015;45:566-74.

18. Alchorne Ade O, Alchorne MM, Silva MM. Occupational dermatosis. An Bras Dermatol. 2010;85:137-45; quiz 146-7.

19. Ibler KS, Jemec GB, Agner T. Exposures related to hand eczema: a study of healthcare workers. Contact Dermatitis. 2012;66:247-53.

20. Alamgir H, Yu S, Chavoshi N, Ngan K. Potential allergy and irritation incidents among health care workers. Aaohn J. 2008;56:281-8.

21. Smedley J, Williams S, Peel P, Pedersen K. Management of occupational dermatitis in healthcare workers: a systematic review. Occup Environ Med. 2012;69:276-9.

22. Holness DL. Occupational skin allergies: testing and treatment (the case of occupational allergic contact dermatitis). Curr Allergy Asthma Rep. 2014;14:410.

23. Baver A, Geier J, Mahler V, Uter W. Contact allergies in the German workforce : Data of the IVDK network from 20032013. Hautarzt. 2015;66):652-64.

24. Mahler V, Geier J, Schnuch A. Current trends in patch testing - new data from the German Contact Dermatitis Research Group (DKG) and the Information Network of Departments of Dermatology (IVDK). J Dtsch Dermatol Ges. 2014;12:583-92.

25. Mahler V, Dickel H, Diepgen TL, Hillen U, Geier J, Kaufmann R, et al. Statement of the German Contact Dermatitis Research Group (DKG) and the German Dermatological Society (DDG) on liability issues associated with patch testing using a patient's own materials. J Dtsch Dermatol. Ges 2016 (in press)

26. Schnuch A, Uter W, Lessmann H, Geier J. Clinical epidemiology and prevention of contact allergies. The Information Network of Departments of Dermatology (IVDK) as a register and surveillance system. Bundesgesundheitsblatt Gesundheitsforschung Gesundheitsschutz. 2012;55:329-37.

27. Schnuch A, Geier J, Lessmann H, Arnold R, Uter W. Surveillance of contact allergies: methods and results of the Information Network of Departments of Dermatology (IVDK). Allergy. 2012;67:847-57.

28. Schubert S, Bauer A, Molin S, Skudlik C, Geier J. Occupational contact sensitization in female geriatric nurses: Data of the Information Network of Departments of Dermatology (IVDK) 2005-2014. J Eur Acad Dermatol Venereol. 2016 (in press).

29. Uter W, Geier J, Baver A, Schnuch A. Risk factors associated with methylisothiazolinone contact sensitization. Contact Dermatitis. 2013;69:231-8.

30. Goncalo M, Ferguson J, Bonevalle A, Bruynzeel DP, Gimenez-Arnau A, Goossens A, et al. Photopatch testing: recommendations for a European photopatch test baseline series. Contact Dermatitis. 2013;68:239-43. 
31. Bruynzeel DP, Ferguson J, Andersen K, Goncalo M, English J, Goossens A, et al. Photopatch testing: a consensus methodology for Europe. J Eur Acad Dermatol. Venereol 2004; 18:679-82.

32. Johansen JD, Aalto-Korte K, Agner T, Andersen KE, Bircher A, Bruze M, et al, European Society of Contact Dermatitis guideline for diagnostic patch testing - recommendations on best practice. Contact Dermatitis. 2015;73:195-221.

33. Agarwal US, Besarwal RK, Gupta R, Agarwal P, Napalia S. Hand eczema. Indian J Dermatol. 2014;59:213-24.

34. Mahler V. Hand dermatitis--differential diagnoses, diagnostics, and treatment options. J Dtsch Dermatol Ges. 2016;14:7-26; quiz 27-8.

35. Andrade P, Goncalo M. Fixed drug eruption caused by etoricoxib--2 cases confirmed by patch testing. Contact Dermatitis. $2011 ; 64: 118-20$.

36. Ibler KS, Jemec GB, Garvey LH, Agner T. Prevalence of delayed-type and immediate-type hypersensitivity in healthcare workers with hand eczema. Contact Dermatitis. 2016;75:223-9.

37. Teixeira V, Coutinho I, Goncalo M. Allergic contact dermatitis to metals over a 20-year period in the Centre of Portugal: evaluation of the effects of the European directives. Acta Med Port. 2014;27:295-303.

38. Boonstra MB, Christoffers WA, Coenraads PJ, Schuttelaar ML. Patch test results of hand eczema patients: relation to clinical types. J Eur Acad Dermatol Venereol. 2015;29):940-7.

39 . Boonstra MB, Christoffers WA, Coenraads PJ, Schuttelaar ML. Patch test results of hand eczema patients: relation to clinical types. J Eur Acad Dermatol Venereol. 2015;29:940-7.

40. Bensefa-Colas L, Telle-Lamberton M, Paris C, Faye S, Stocks SJ, Luc A, et al. Occupational allergic contact dermatitis and major allergens in France: temporal trends for the period 2001-2010. Br J Dermatol. 2014;171:1375-85.

41. Gameiro A, Coutinho I, Ramos L, Goncalo M. Methylisothiazolinone: second 'epidemic' of isothiazolinone sensitization. Contact Dermatitis. 2014;70:242-3.

42. Goncalo M, Goossens A. Whilst Rome burns: the epidemic of contact allergy to methylisothiazolinone. Contact Dermatitis. 2013;68:257-8.

43. Schwensen JF, Uter W, Bruze M, Svedman C, Goossens A, Wilkinson $M$, et al. The epidemic of methylisothiazolinone: a European prospective study. Contact Dermatitis. 2016 (in press)

44. Goncalo M. Methylisothiazolinone in rinse-off products: additional fuel to the world epidemics of allergic contact dermatitis to isothiazolinones. $\mathrm{Br} \mathrm{J}$ Dermatol. $2015 ; 173: 11$.
45. Leiva-Salinas M, Frances $L$, Silvestre JF. Update on allergic contact dermatitis due to methylchloroisothiazolinone/ methylisothiazolinone and methylisothiazolinone. Actas Dermosifiliogr. 2014;105:840-6.

46. Lundov MD, Thyssen JP, Zachariae C, Johansen JD. Prevalence and cause of methylisothiazolinone contact allergy. Contact Dermatitis. 2010;63:164-7.

47. Lundov MD, Opstrup MS, Johansen JD. Methylisothiazolinone contact allergy--growing epidemic. Contact Dermatitis. 2013;69:271-5.

48. Lammintausta K, Aalto-Korte K, Ackerman L, Alanko K, Berry P, Hasan T, Kaminska R, Korhonen L, Laukkanen A, Liippo J, Pesonen M, Rantanen T, Riekki R, Suuronen K. An epidemic of contact allergy to methylisothiazolinone in Finland. Contact Dermatitis. 2014;70:184-5.

49. Vauhkala AR, Pesonen M, Suomela S, Kuuliala O, Suuronen K, Aalto-Korte K. Occupational contact allergy to methylchloroisothiazolinone/methylisothiazolinone and methylisothiazolinone. Contact Dermatitis. 2015;73:150-6.

50. Aalto-Korte K, Ackermann L, Henriks-Eckerman ML, Valimaa J, Reinikka-Railo H, et al. 1,2-benzisothiazolin-3-one in disposable polyvinyl chloride gloves for medical use. Contact Dermatitis. 2007;57:365-70.

51. Carøe TK, Ebbehøj N, Agner T. A survey of exposures related to recognized occupational contact dermatitis in Denmark in 2010. Contact Dermatitis. 2014;70:56-62.

52. Skoet R, Olsen J, Mathiesen B, Iversen L, Johansen JD, Agner T. A survey of occupational hand eczema in Denmark. Contact Dermatitis. 2004;51:159-66.

53. Geier J, Lessmann H, Mahler V, Pohrt U, Uter W, Schnuch A. Occupational contact allergy caused by rubber gloves--nothing has changed. Contact Dermatitis. 2012;67:149-56.

54. Gielen K, Goossens A. Occupational allergic contact dermatitis from drugs in healthcare workers. Contact Dermatitis. $2001 ; 45: 273-9$.

55. Antunes J, Silva R, Pacheco D, Travassos R, Filipe P. Occupational contact allergy to cephalosporins. Dermatol Online J. $2011 ; 17: 13$.

56. Foti C, Bonamonte D, Trenti R, Vena GA, Angelini G. Occupational contact allergy to cephalosporins. Contact Dermatitis. 1997;36:104-5.

57. Rai R, Dinakar D, Kurian SS, Bindoo YA. Investigation of contact allergy to dental materials by patch testing. Indian Dermatol Online J. 2014;5:282-6.

58. Ramos L, Cabral R, Goncalo M. Allergic contact dermatitis caused by acrylates and methacrylates - a 7-year study. Contact Dermatitis. 2014;71:102-7.

59. Holness DL. Return-to-work barriers for workers with contact dermatitis. Contact Dermatitis. 2003;49:273-5. 